\title{
Wheat-dependent exercise-induced anaphylaxis associated with a facial soap
}

\author{
Shuichi Iwamoto, ${ }^{1}$ Noboru Hagino, ${ }^{2}$ Tetsuya Tanimoto, ${ }^{1,3,4}$ Eiji Kusumi ${ }^{1,4}$ \\ ${ }^{1}$ Department of Internal Medicine, Navitas Clinic, Tachikawa, Japan; \\ 2Department of Hematology and Rheumatology, Teikyo Universiy Chiba Medical Center, Ichihara, Japan; \\ ${ }^{3}$ Cancer Institute, Japanese Foundation for Cancer Research, Tokyo, Japan; \\ ${ }^{4}$ Division of Social Communication System for Advanced Clinical Research, The Institute of Medical Science, The University of Tokyo, Tokyo, Japan
}

Correspondence to Dr Tetsuya Tanimoto, tetanimot@yahoo.co.jp

\section{DESCRIPTION}

A 27-year-old woman presented to our clinic with sudden-onset of nasal discharge and bilateral periorbital oedema (figures 1 and 2). Although she had been well until the morning, she noticed the extensive, rapidly progressing symptom during exercise at gymnasium after lunch containing fried-wheat. She had no history of food allergies. We performed a radioallergosorbent test, and it was positive for wheat. We made a diagnosis of socalled, wheat-dependent exercise-induced anaphylaxis (WDEIA). ${ }^{1}$ WDEIA is one of the most important clinical phenotypes of adult wheat allergy. Although most food-induced allergic reactions occur on first known

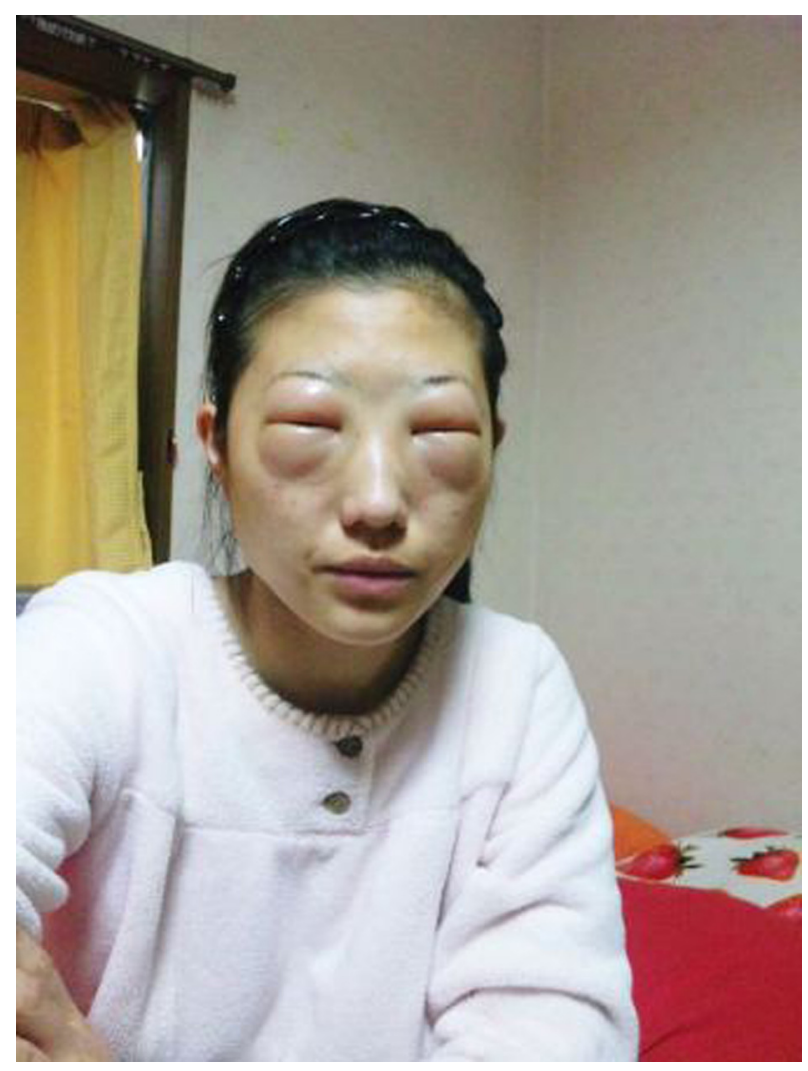

Figure 1 Bilarteral periorbital oedema. oral exposure, WDEIA due to hydrolysed wheat protein (HWP), which can be used in cosmetics, shampoo, or hair conditioner, has been recently reported. ${ }^{2-4}$ In Japan, a mail order soap, which sold 46.5 million bars to 4.6 million customers between 2004 and 2010, has caused at least 569 cases to suffer WDEIA. The development of their WDEIA could be induced by primary sensitisation to HWP in the facial soap and accompanying sensitisation to natural wheat protein. The causative allergen of the mass casualties was due to the HWP called Glupal19S of the soap. ${ }^{4}$ We found her mother had the soap and confirmed the allergen in the present case by a skin-prick testing of Glupal-19S. She was treated with antihistaminergic agents, and her condition improved over the next several days. Her symptom has not recurred with prevention of exercise after meals, and she could take wheat-containing foods. Pathophysiology is not fully understood, but it is reported that cutaneous mast cells from patients with exercise-induced anaphylaxis presented morphologic changes similar to those observed in atopic patients following exercise.$^{5}$ Clinicians should always expect the unexpected cause of allergen, and comprehensive history taking including a patient's family is essential.

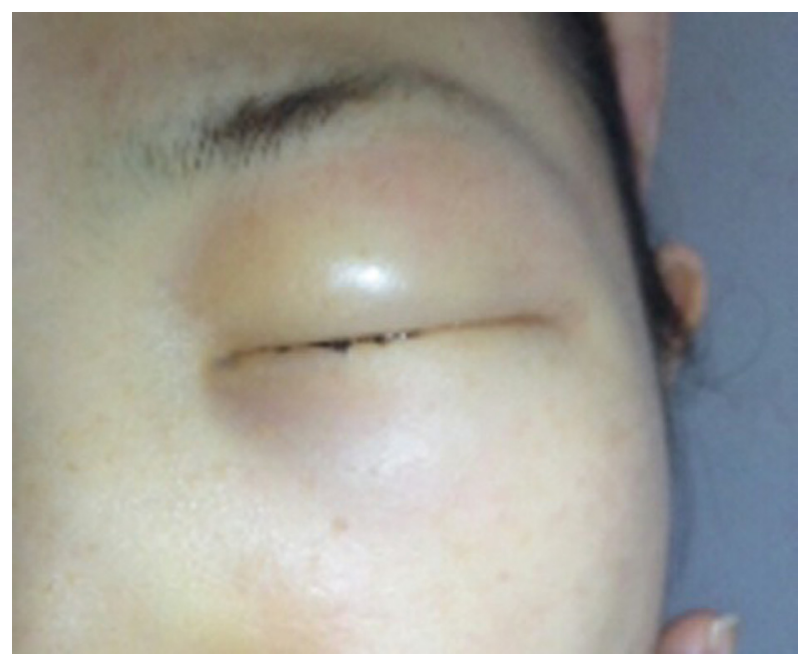

Figure 2 A close-up picture of periorbital oedema. 


\section{BMJ Case Reports}

\section{Learning points}

- A comprehensive history taking including a patient's family is essential to search for allergen.

- WDEIA can be caused by an unexpected allergen, such as a soap containing a hydrolysed wheat protein. Patients with WDEIA may take wheat-containing foods unless they exercise.

Competing interests None.

Patient consent Obtained.

\section{REFERENCES}

1. Wong GK, Huissoon AP, Goddard S, et al. Wheat dependent exercise induced anaphylaxis: is this an appropriate terminology? J Clin Pathol 2010;63:814-7.

2. Fukutomi $\mathbf{Y}$, Itagaki $Y$, Taniguchi $M$, et al. Rhinoconjunctival sensitization to hydrolyzed wheat protein in facial soap can induce wheatdependent exercise-induced anaphylaxis. J Allergy Clin Immunol 2011;127:531-533.e1-3.

3. Chinuki Y, Kaneko S, Sakieda K, et al. A case of wheat-dependent exerciseinduced anaphylaxis sensitized with hydrolysed wheat protein in a soap. Contact Derm 2011;65:55-7.

4. The Rheumatism \& Allergy Information Center. Information concerning wheat allergy. http://www.allergy.go.jp/allergy/flour/index.html laccessed 3 February 2012).

5. Barg W, Medrala W, Wolanczyk-Medrala A. Exercise-induced anaphylaxis: an update on diagnosis and treatment. Curr Allergy Asthma Rep 2011;11:45-51.

This pdf has been created automatically from the final edited text and images.

Copyright 2012 BMJ Publishing Group. All rights reserved. For permission to reuse any of this content visit http://group.bmj.com/group/rights-licensing/permissions.

BMJ Case Report Fellows may re-use this article for personal use and teaching without any further permission.

Please cite this article as follows (you will need to access the article online to obtain the date of publication).

Iwamoto S, Hagino N, Tanimoto T, Kusumi E. Wheat-dependent exercise-induced anaphylaxis associated with a facial soap. BMJ Case Reports 2012;10.1136/bcr.01.2012.5641, Published XXX

Become a Fellow of BMJ Case Reports today and you can:

- Submit as many cases as you like

- Enjoy fast sympathetic peer review and rapid publication of accepted articles

- Access all the published articles

- Re-use any of the published material for personal use and teaching without further permission

For information on Institutional Fellowships contact consortiasales@bmjgroup.com

Visit casereports.bmj.com for more articles like this and to become a Fellow

Keep up to date with all published cases by signing up for an alert (all we need is your email address) http://casereports.bmj.com/cgi/alerts/etoc 